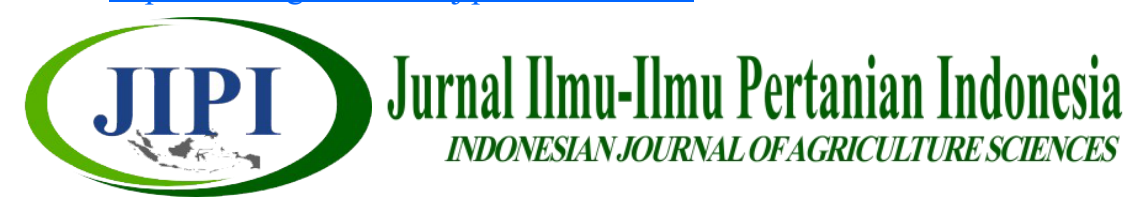

\title{
PEMANFAATAN BIOMASSA GULMA PAITAN (Tithonia diversifolia) (Hemsley) A. Gray SEBAGAI PUPUK KOMPOS DALAM MENINGKATAN HASIL KACANG TANAH
}

\author{
Desy Aryani ${ }^{1}$, Uswatun Nurjanah ${ }^{1 *}$, Hasanudin ${ }^{2}$ \\ 1Program Studi Agroekoteknologi, Fakultas Pertanian Universitas Bengkulu \\ 2Program Studi Ilmu Tanah, Fakultas Pertanian Universitas Bengkulu \\ *Corresponding Author : uswatun_nurjannah@gmail.com
}

\begin{abstract}
[THE USE OF PAITAN BIOMASS (Tithonia diversifolia) (Hemsley) A. Gray AS A FERTILIZER IN INCREASING PEANUT YIELD]. Peanuts are one of the food crops having high economic value due to their nutritional content, especially high protein and fat. Peanut crop production has decreased due to infertile land with poor in nutrients. Efforts to increase peanut production is by including organic paitan ( $T$. diversifolia) provision. This study aims to obtain the optimum dose of $T$. diversifolia compost on the yield of peanuts. This research was carried out in Pekik Nyaring Village, Bengkulu, with a height of $\pm 25 \mathrm{~m}$ above sea level, from February to April 2018. The design used was a complete randomized block design with a single factor consisting of 6 levels of treatment with four replications. Factor dosage of paitan compost fertilizer ( $T$. diversifolia) is 0 tons/hectares, 5 tons/hectares, 10 tons/hectares, 15 tons/hectares, 20 tons/hectares, and 25 tons/hectares. Data were analyzed using analysis of variance at a $5 \%$ level. The results showed that the optimum dose of 15.5 tons/hectares produced 6.54 branches. The dosage of $T$. diversifolia compost 25 tons/ hectares produced the highest number of pithed pods (36.08 pieces), the heaviest pith weighted pods (111.58 g), and the heaviest seed weight $(87.06 \mathrm{~g})$.
\end{abstract}

Keyword: peanut, compost, paitan, Tithonia diversifolia

\begin{abstract}
ABSTRAK
Kacang tanah merupakan salah satu tanaman pangan yang mempunyai nilai ekonomi tinggi karena kandungan gizinya terutama protein dan lemak yang tinggi. Produksi tanaman kacang tanah mengalami penurunan hasil yang disebabkan oleh lahan yang kurang suburakibat tergolong miskin akan unsur hara. Upaya peningkatan produksi kacang tanah antara lain dengan pemberian bahan organik paitan (Tithonia diversifolia). Penelitian ini bertujuan untuk mendapatkan dosis optimum pupuk kompos T. diversifolia terhadap hasil kacang tanah. Penelitian ini dilaksanakan di Desa Pekik. Nyaring Bengkulu dengan ketinggian tempat $\pm 25 \mathrm{~m}$ di atas permukaan laut, dari bulan Februari sampai April 2018. Disain yang digunakan ialah rancangan acak kelompok lengkap dengan faktor tunggal yang terdiri atas 6 taraf perlakuan dengan 4 ulangan. Faktor dosis pupuk kompos paitan (T. diversifolia) yaitu 0 ton/ha, 5 ton/ha, 10 ton/ha, 15 ton/ha, 20 ton/ha, dan 25 ton/ha. Data dianalisis menggunakan analisis keragaman pada taraf $5 \%$. Hasil penelitian menunjukkan dosis optimum sebesar 15,5 ton/ha menghasilkan jumlah cabang sebanyak 6,54 cabang. Dosis pupuk kompos T. diversifolia 25 ton/ha menghasilkan jumlah polong bernas terbanyak (36,08 buah), bobot polong bernas terberat $(111,58 \mathrm{~g})$ dan bobot biji terberat $(87,06 \mathrm{~g})$.
\end{abstract}

Kata kunci: kacang tanah, pupuk kompos, paitan, Tithonia diversifolia 


\section{PENDAHULUAN}

Kacang tanah (Arachis hypogaea L.) merupakan salah satu komoditi tanaman pangan yang mempunyai nilai ekonomi tinggi karena kandungan gizinya terutama protein dan lemak yang tinggi (Raja et.al., 2013). Tanaman ini banyak digunakan sebagai bahan makanan dan bahan baku industri. Produksi tanaman kacang tanah khususnya di daerah Bengkulu selama 5 tahun cenderung mengalami penurunan. Produksi tanaman kacang tanah beberapa tahun terakhir ini mengalami fluktuasi, pada tahun 2011 sebanyak 691,289 ton, tahun 2012 produksi mencapai 712,857 ton, tahun 2013 produksi kacang tanah tercatat 701,680 ton, dan pada tahun 2014 produksi kacang tanah mencapai 683,896 ton. Tahun 2015 produksi kacang tanah masih mengalami penurunan dan tercacat produksi sebanyak 605,449 ton (BPS, 2016).

Penurunan produksi tersebut disebabkan oleh beberapa faktor, di antaranya teknik budidaya, serangan hama penyakit, varietas yang digunakan, kondisi tanah, lamanya periode kekeringan serta luas lahan yang semakin sedikit karena telah beralih fungsi menjadi pemukiman. Tanah ultisol salah satu kendala yang dihadapi di Bengkulu. Tanah ultisol termasuk bagian terluas dari lahan kering yang ada di Indonesia yaitu 45.794 .000 ha atau sekitar $25 \%$ dari total luas daratan Indonesia. Jenis tanah ini memiliki kandungan bahan organik yang sangat rendah dengan tekstur tanah liat hingga liat berpasir. Sifatsifat ini sering menghambat pertumbuhan tanaman (Hardjowigeno, 1993). Kacang tanah merupakan tanaman yang membutuhkan tanah gembur agar dapat ditembus oleh ginofor dengan mudah sehingga proses pembentukan polong tidak mengalami hambatan (Habiby et al., 2013).

Usaha yang dapat dilakukan untuk meningkatkan dan mempertahankan kesuburan tanah adalah dengan cara pemupukan. Berdasarkan sumber pembuatannya pupuk dapat dikelompokkan menjadi dua, yaitu pupuk organik dan pupuk sintetik. Pupuk organik adalah pupuk yang berasal dari makhluk hidup seperti kotoran, sampah, kompos dan limbah tanaman. Penggunaan pupuk organik dapat meningkatkan kolonisasi dan aktivitas fungi mikoriza arbuskula yang berperan terhadap kesuburan tanah (Nusantara et al., 2019). Bahan organik selain dapat meningkatkan kesuburan tanah juga mempunyai peran penting dalam memperbaiki sifat fisik tanah. Bahan organik dapat meningkatkan agregasi tanah serta membuat struktur tanah menjadi lebih remah dan mudah diolah (Prasetyo et al., 2016).

Pemberian pupuk organik bertujuan untuk memelihara kesuburan tanah dan mengurangi penggunaan pupuk sintetik. Penggunaan pupuk organik diharapkan dapat memperbaiki sifat fisik, kimia dan biologi tanah, sehingga dapat menyuburkan tanah dan membantu dalam menyumbangkan unsur hara yang dapat digunakan dalam meningkatkan hasil kacang tanah (Marlina et al., 2015). Jenis pupuk organik sangat beragam, salah satunya adalah pupuk kompos. Hasil tanaman tomat yang dipupuk dengan kompos rumput 30 ton/ha dan kombinasi $50 \%$ kontrol +15 ton/ha kompos rumput hasilnya lebih tinggi dibandingkan pupuk sintetik dosis rekomendasi (Kurnia et al., 2019). Bahan kompos gulma paitan (Tithonia diversifolia) dapat menggantikan 50\% pupuk sintetik (Hakim et al., 2012). Selain itu pemberian paitan dapat menurunkan $\mathrm{Al}$, serta meningkatkan $\mathrm{pH}$ tanah, bahan organik, kandungan hara N, P, K, Ca dan Mg tanah. Bahan organik T. diversifolia pada dosis 3-9 ton/ha mampu meningkatkan pertumbuhan tanaman namun berpengaruh tidak nyata terhadap hasil tanaman kacang tanah (Raja et al., 2013). Paitan memiliki kandungan $\mathrm{N}$ berkisaran antara 3,1-5,5\%, $\mathrm{K}$ sebesar 2,5-5,5\% dan P sebesar 0,2-0,55\%.

Paitan merupakan gulma yang banyak menetap di areal pertanian maupun di areal non pertanian (Ardi et al., 2003). Gulma ini dapat dikendalikan dengan mengelola gulma sehingga bermanfaat, yaitu sebagai sumber pupuk hijau pada tanaman (Hutomo et al., 2015). $T$. diversifolia dapat diperbanyak melalui biji, stek batang atau tunas dan dapat dipangkas setiap tahun tanpa harus menanam kembali (Hartatik, 2007; Hakim \& Agustian, 2012). Penelitian ini bertujuan untuk mendapatkan dosis optimum pupuk kompos paitan (T. diversifolia) terhadap hasil kacang tanah.

\section{METODE PENELITIAN}

Penelitian ini dilaksanakan pada bulan Februari sampai Mei 2018 bertempat di Desa Pekik Nyaring Bengkulu Tengah dengan ketinggian tempat $\pm 25 \mathrm{~m}$ di atas permukaan laut dan Laboratorium Argonomi Fakultas Pertanian Universitas Bengkulu. Penelitian ini menggunakan Rancangan Acak Kelompok Lengkap (RAKL) dengan faktor tunggal. Faktor yang digunakan adalah dosis pupuk kompos $T$. diversifolia dengan 6 taraf yaitu $\mathrm{D}_{0}=0$ ton $/ \mathrm{ha}, \mathrm{D}_{1}=5$ ton $/ \mathrm{ha}, \mathrm{D}_{2}=10$ ton $/ \mathrm{ha}$, $\mathrm{D}_{3}=15$ ton/ha, $\mathrm{D}_{4}=20$ ton $/$ ha, dan $\mathrm{D}_{5}=25$ ton $/$ ha, setiap satuan percobaan empat kali, sehingga diperoleh 24 satuan percobaan.

Kompos T.diversifolia dibuat dengan cara mencacah daun ukuran 3-5 cm dan menempatkannya pada terpal. Selanjutnya disiramkan larutan EM4 sebanyak $300 \mathrm{~mL}$ pada tumpukan paitan, setelah itu terpal ditutup. Suhu dipertahankan pada kisaran $45-60{ }^{0} \mathrm{C}$ dan kelembaban $40-50 \%$ dengan cara melakukan pembalikan setiap hari. Proses pengomposan dilakukan selama satu bulan hingga komposnya matang.

Lahan yang digunakan dibebaskan dari gulma dan diolah sedalam $20 \mathrm{~cm}$ hingga gembur. Petak percobaan dibuat dengan ukuran $1,5 \mathrm{mx} 1,5 \mathrm{~m}$. Jarak antar petak $50 \mathrm{~cm}$ dan jarak antar blok $100 \mathrm{~cm}$. 
Penanaman dilakukan dengan cara menugal tanah sedalam 2-3 cm Setiap lubang ditanam sebanyak satu benih. Jarak tanam yang digunakan yaitu $30 \mathrm{~cm} \mathrm{x}$ $30 \mathrm{~cm}$ sehingga diperoleh 25 tanaman/petak. Tanaman sampel yang digunakan sebanyak 9 tanaman/petak.

Kompos T. diversifolia diaplikasikan satu minggu sebelum tanam. Pemberiannya dilakukan dengan cara mencampur dengan tanah sesuai dosis perlakuan. Pupuk rekomendasi yang digunakan adalah Urea $100 \mathrm{~kg} / \mathrm{ha}$, SP-36 $100 \mathrm{~kg} / \mathrm{ha}$ dan $\mathrm{KCl} 100 \mathrm{~kg} / \mathrm{ha}$ (Muhsin et al., 2017). Dosis yang diberikan yaitu setengah dari dosis rekomendasi. Pemupukan dilakukan bersamaan saat tanam dengan membuat larikan pada baris tanaman kemudian ditutup tanah setelah larikan diisi pupuk.

Pemeliharaan meliputi penyiraman, pembumbunan, pengendalian hama dan penyakit. Penyiraman dilakukan sebanyak satu kali yaitu sore hari. Pembumbunan dilakukan pada saat berumur 2 minggu setelah tanam (mst) dan 4 mst dengan menggunakan cangkul dan sekaligus pengendalian gulma. Pengendalian hama dan penyakit dilakukan secara kimiawi dengan dengan menggunakan Sevin dengan dosis $5 \mathrm{~g} / 10 \mathrm{~L}$ air yang diaplikasikan menggunakan knapsack spayer pada umur 2-4 mst.

Pemanenan dilakukan setelah tanaman berumur $14 \mathrm{mst}$ dengan ciri sebagian besar daun sudah berubah warna dari hijau menjadi kekuningan.Pemanenan dilakukan dengan cara mencabut seluruh bagian tanaman.

Pengamatan meliputi komponen pertumbuhan dan hasil. Komponen pertumbuhan yang diamati yaitu kehijauan daun yang diamati pada umur 5 mst dengan menggunakan Soil Plant Analysis Development (SPAD), dan jumlah cabang tanaman (buah) yang dihitung saat tanaman berumur 2 mst sampai tanaman berbunga. Komponen hasil yang diamati seperti jumlah polong bernas/tanaman (buah) yang diamati setelah panen dengan cara menghitung polong yang berisi, bobot polong bernas/petak (g) yang diamati dengan cara mengeringkan polong berisi di bawah sinar matahari selama 3 hari kemudian ditimbang menggunakan timbangan digital, dan bobot biji/petak (g) dilakukan dengan cara mengeringkan biji di bawah sinar matahari selama 3 hari kemudian ditimbang menggunakan timbangan digital.

Data yang diperoleh dianalisis secara statistik dengan Analisis Varian (ANAVA) menggunakan uji $\mathrm{F}$ taraf 5\%. Hasil uji $\mathrm{F}$ yang menunjukkan berpengaruh nyata dilanjutkan dengan Polinomial Orthogonal taraf $5 \%$.

\section{HASIL DAN PEMBAHASAN}

Pada saat penelitian curah hujan rata-rata cukup tinggi yakni sebesar $313 \mathrm{~mm} /$ bulan dengan jumlah hari hujan rata-rata 16 hari/bulan. Suhu udara minimum rata-rata per bulan di lokasi percobaan adalah $24,9^{\circ} \mathrm{C}$, sedangkan suhu udara maksimum rata-rata per bulannya dapat mencapai $28,2{ }^{\circ} \mathrm{C}(\mathrm{BMKG}, 2018)$.
Secara umum tanaman tumbuh dengan baik, meskipun ada gangguan dari organisme pengganggu tanaman (OPT) yaitu hama belalang dan ulat jengkal yang mengakibatkan daun tanaman menjadi berlubang. Hama tersebut dikendalikan dengan insektisida Sevin dengan dosis $5 \mathrm{~g} / 10 \mathrm{~L}$ air yang diaplikasikan menggunakan knapsack spayer pada umur 2-4 mst pada sore hari.

Penyiraman dilakukan setiap sore hari jika tidak turun hujan. Pembumbunan dilakukan dua kali yakni saat umur tanaman $4 \mathrm{mst}$ dan pada $10 \mathrm{mst}$. Gulma disiangi sebanyak dua kali selama masa tanam, yaitu ketika umur tanaman 3 mst dan 5 mst. Panen dilakukan pada saat tanaman berumur 98 hari (14 mst).

Hasil analisis data menunjukkan bahwa aplikasi pupuk kompos paitan berpengaruh nyata $(\mathrm{P} \leq 0,05)$ pada variabel jumlah cabang, jumlah polong bernas/ tanaman, bobot polong bernas/petak, dan bobot biji/ petak. Pemberian pupuk kompos dapat meningkatkan kesuburan tanah untuk menunjang pertumbuhan tanaman. Bahan organik seperti paitan mempunyai kelebihan yaitu waktu dekomposisi relatif cepat serta unsur hara yang terkandung tinggi dan baik untuk pertumbuhan tanaman (Oyerinde et al., 2009).

Perlakuan aplikasi dosis pupuk kompos paitan berpengaruh tidak nyata $(\mathrm{P}>0,05)$ terhadap kehijauan daun. Namun dosis kompos paitan 10 ton/ha cenderung menghasilkan kehijauan daun tertinggi yaitu sebesar 41,4 dibandingkan dengan dosis kompos paitan lainnya.

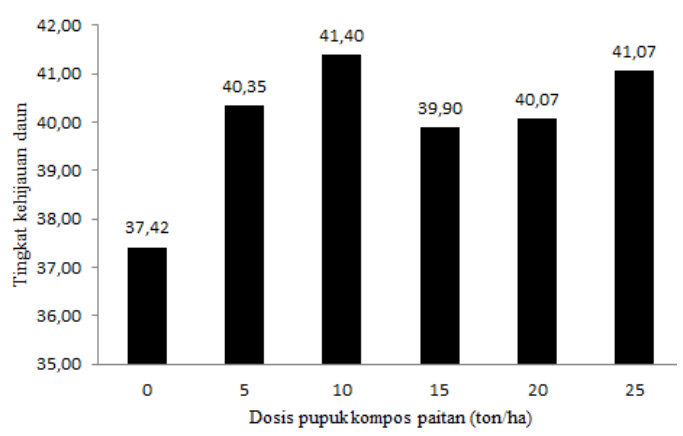

Gambar 1. Tingkat kehijauan daun pada perlakuan pupuk kompos paitan

Kehijauan daun memiliki hubungan dengan unsur hara $\mathrm{N}$ yang dapat dimanfaatkan oleh tanaman. Unsur $\mathrm{N}$ berperan dalam pembentukan hijau daun yang berguna dalam proses fotosintesis (Lingga \& Marsono, 2010). Oleh karena itu unsur $\mathrm{N}$ dapat berfungsi menyehatkan pertumbuhan daun, daun tanaman menjadi lebih lebar, dan warna daun yang lebih hijau (Sutedjo, 2002).

Peningkatan dosis kompos paitan yang diaplikasikan meningkatkan variabel jumlah cabang dengan mengikuti persamaan $\mathrm{Y}=3,8044+0,3534 \mathrm{x}-0,0114 \mathrm{x}^{2}\left(\mathrm{R}^{2}=\right.$ 0,916) (Gambar 2). 


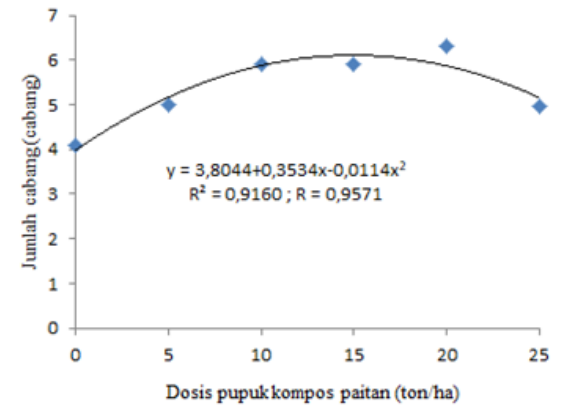

Gambar 2. Hubungan dosis pupuk kompos paitan dan jumlah cabang kacang tanah

Peningkatan dosis pupuk kompos paitan dari 0 ton/ha $-15,5$ ton/ha akan meningkatkan jumlah cabang rata-rata sebanyak 6,54 cabang. Peningkatan jumlah cabang disebabkan karena terpenuhinya unsur hara $\mathrm{N}$ pada tanaman kacang tanah. Kebutuhan N pada tanaman kacang tanah yaitu sebesar 22,5 g/petak sedangkan yang diberikan yaitu sebesar $66,15 \mathrm{~g} /$ petak. Gambar di atas juga menunjukkan bahwa ketika dosis optimum pupuk kompos paitan sudah tercapai maka penambahan dosis berikutnya akan diikuti berkurangnya jumlah cabang kacang tanah. Paitan dapat membentuk senyawa yang mempunyai efek negatif, yaitu bersifat alelopati yang dapat menghambat pertumbuhan tanaman (Kurniansyah, 2010).

Jumlah polong merupakan saalah satu indikator hasil kacang tanah. Hasil penelitian ini menunjukkan dosis pupuk paitan memberikan pengaruh nyata pada jumlah polong bernas (Gambar 3).

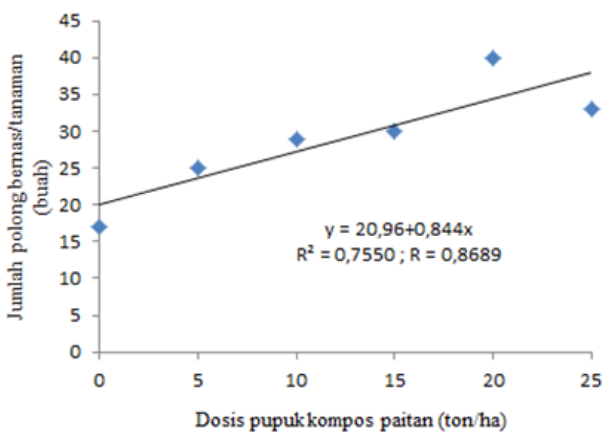

Gambar 3. Hubungan dosis pupuk kompos paitan dan jumlah polong bernas/tanaman

Pemberian dosis pupuk kompos paitan antara 0 ton/ha-25 ton/ha mampu meningkatkan jumlah polong bernas rata-rata sebanyak 0,844 buah. Variabel jumlah polong bernas kacang tanah meningkat seiring dengan meningkatnya dosis pupuk kompos paitan berdasarkan dengan persamaan $Y=20,96+0,844 x \quad\left(R^{2}=0,755\right)$. Peningkatan jumlah polong bernas disebabkan tercukupinya unsur hara $\mathrm{P}$ dalam tanah. Semakin tinggi dosis pupuk kompos paitan maka semakin tinggi ketersediaan unsur hara $\mathrm{P}$ yang mempengaruhi pengisian polong sehingga meningkatkan jumlah polong bernas/tanaman (Irdiawan \& Rahmi, 2002).

Secara umum hasil penelitian ini menunjukkan semakin tinggi dosis pupuk kompos paitan maka semakin meningkat bobot polong bernas/petak mengikuti fungsi linear $\mathrm{Y}=57,43+2,739 \mathrm{x} \quad\left(\mathrm{R}^{2}=0,834\right)$. Atas dasar fungsi ini dapat dijelaskan bahwa setiap kenaikan satu satuan dosis pupuk kompos paitan dari 0 ton/ha- 25 ton/ha mampu meningkatkan bobot polong bernas rata-rata sebesar 2,739 g (Gambar 4).

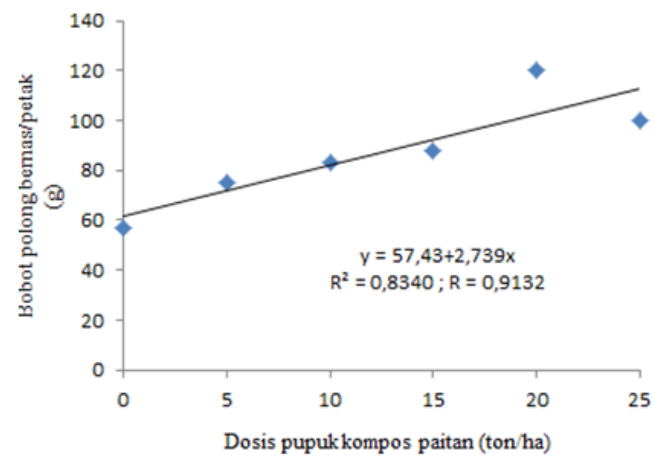

Gambar 4. Hubungan dosis pupuk kompos paitan dan bobot polong bernas/petak

Peningkatan bobot polong bernas/tanaman diikuti dengan bertambahnya jumlah polong bernas/petak. Paitan memiliki kandungan $P$ yang baik untuk proses pembentukan polong sehingga bobot polong bernas memiliki pengaruh yang nyata pada penelitian ini. Phiri et al. (2003) menyatakan T. diversivolia telah banyak digunakan sebagai pupuk organik yang mampu meningkatkan unsur $\mathrm{P}$ pada tanahtanah kahat $\mathrm{P}$ di Colombia. Kecukupan unsur $\mathrm{P}$ alam tanah sangat penting untuk pertumbuhan dan produksi kedelai. Sinclair (1994) menyatakan tersedianya hara P dalam tanah meningkatkan ketersediaan unsur $\mathrm{N}$ untuk pertumbuhan dan produksi tanaman.

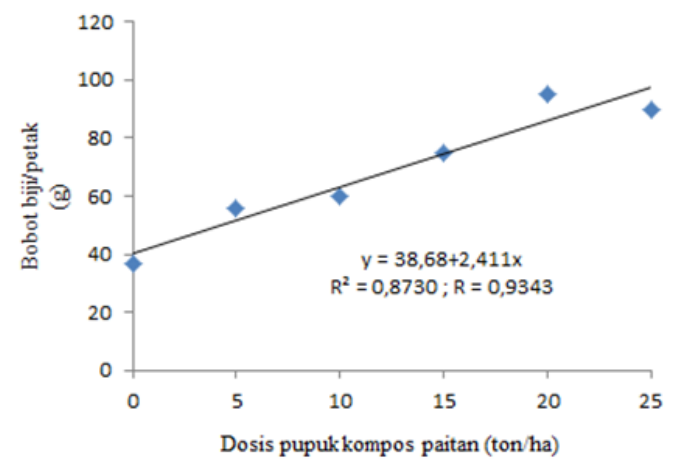

Gambar 5. Hubungan dosis pupuk kompos paitan dan bobot biji/petak 
Bobot biji/petak meningkat seiring dengan meningkatnya dosis pupuk paitan berdasarkan fungsi linear $\mathrm{Y}=$ $38,68+2,411 \mathrm{x}$ dengan nilai koefisien determinasi $\left(\mathrm{R}^{2}\right)$ sebesar 0,873 . Setiap kenaikan satu satuan dosis pupuk kompos paitan dari 0 ton/ha hingga 25 ton/ha mampu meningkatkan bobot biji/petak rata-rata sebesar 2,411g (Gambar 5). Bertambahnya suplai $P$ dalam tubuh tanaman akan meningkatkan metabolisme yang meningkatkan pembentukan biji sehingga bobot biji/petak meningkat (Hidayat, 2008). Hasil analisis unsur hara $P$ tanaman kacang tanah telah tercukupi sebesar 82,68 g/petak dari kebutuhan awal yaitu sebesar 33,75 g/petak Terpenuhinya unsur hara $\mathrm{P}$ masih menunjukkan pola linear. Hal ini diduga unsur hara $\mathrm{P}$ meskipun telah terpenuhi kebutuhannya diduga tidak dapat terserap dengan baik oleh tanaman.

\section{KESIMPULAN}

Pemberian dosis pupuk kompos paitan T. diversifolia 10 ton/ha menghasilkan tingkat kehijauan daun tertinggi. Jumlah cabang terbanyak dihasilkan pada dosis 15,5 ton/ha. Kompos paitan T. diversifolia yang diberikan berpengaruh positif terhadap variabel jumlah polong bernas/tanaman, bobot polong bernas/petak, dan bobot biji/petak.

\section{DAFTAR PUSTAKA}

Ardi, D., Jahja \& Wenny. (2013). Substitusi nitrogen dari urea dengan Tithonia (Tithonia diversifolia) dan pengaruhnya terhadap pertumbuhan Gambir (Uncaria gambir Roxb.) Muda. Stigma, 11(3), 202-208.

Badan Meterologi Klimatologi \& Geofisika. (2018). Curah hujan, Kelembaban, Suhu Udara dan Penyinaran Matahari. Stasiun Klimatologi Bengkulu Pulau Baii, Bengkulu.

Badan Pusat Statistik. 2016. Produksi kacang tanah. htttp://www.bps.go.id/linkTableDi namis/view/ id874. 10 Oktober 2017.

Habiby, M. R., Damatik, S. \& Ginting, J. (2013). Pertumbuhan dan produksi kacang tanah pada beberapa pengelolaan tanah Inseptisol dan pemberian pupuk kascing. Jurnal Agroekoteknologi, 1(4), 1183-1194.

Hakim, N. \& Agustian. (2012). Tithonia Untuk Pertanian Berkelanjutan. Andalas University Press., Sumatera Barat.

Hakim, N., Agustian \& Mala, Y. (2012). Application of organic fertilizer Tithonia plus to control iron toxicity and reduce commercial fertilizer application on new paddy field. J. Trop. Soils, 17, 135-142. DOI: http://dx.doi.org/10.5400/jts.2012.v17i2. 135-142.
Hardjowigeno. (1993). Klasifikasi Tanah dan Pedogenesis. Akademika Pressindo, Jakarta.

Hartatik, W. (2007). Tithonia diversifolia sebagai pupuk hijau. Warta Penelitian dan Pengembangan Pertanian. 29(5), 3-5.

Hidayat, N. (2008). Pertumbuhan dan produksi kacang tanah (Arachis hypogea L.) varietas Lokal Madura pada berbagai jarak tanam dan dosis pupuk fospor. Jurnal Agrovigor, 1(1), 55-63. DOI: https://doi. org/10.21107/agrovigor. v1i1.232.

Hutomo I. P., Mahfudz \& Laude, S. (2015). Pengaruh pupuk hijau Tithonia diversifolia terhadap pertumbuhan dan hasil tanaman jagung (Zea mays L.). Jurnal Agrotekbis, 3(4), 475-481.

Irdiawan, R. \& Rahmi, A. (2002). Pengaruh jarak tanam dan pemberian bokhasi pupuk kandang ayam terhadap pertumbuhan dan hasil kacang tanah (Arachis hypogaea L.). J. Agrifor. 1(2), $31-36$

Kurnia, S.D., Setyowati, N. \& Alnopri. (2019). Pengaruh kombinasi dosis kompos gulma dan pupuk sintetik terhadap pertumbuhan dan hasil tanaman tomat (Lycopersicum esculentum Mill.). Jurnal Ilmu-Ilmu Pertanian Indonesia, 21(1), 15-21. DOI: https://doi.org/10.31186/jipi.21.1. 15-21.

Kurniansyah, D. (2010). Produksi kedelai organik panen kering dari dua varietas kedelai dengan berbagai jenis pupuk organik. Skripsi. Institut Pertanian Bogor, Bogor.

Lingga, P. \& Marsono. (2010). Petunjuk Penggunaan Pupuk. Penebar Swadaya, Jakarta

Marlina, N., Aminah, R.I.S., Rosmiah \& Setel, L.R. (2015). Aplikasi pupuk kandang kotoran ayam pada tanaman kacang tanah (Arachis hypogeae L.). Biosaintifika, 7(2), 136-141. DOI: https:// doi.org/10.15294/biosaintifika.v7i2.3957.

Muhsin, K., Patadunjan, Y. \& M. Basir, M. (2017). Respon tanaman kacang tanah terhadap berbagai jenis pupuk pada Entisols di Kelurahan Tondo. Jurnal Mitra Sains, 1(5), 1-11.

Nusantara, A.D., Bertham, Y.H., Junedi, A., Pujiwati, H. \& Hartal. (2019). Pemanfaatan mikroba untuk meningkatkan pertumbuhan dan hasil kedelai di tanah pesisir. Jurnal Ilmu-Ilmu Pertanian Indonesia, 21(1), 37-43. DOI: https://doi.org/ 10.31186/jipi.21.1.37-43.

Oyerinde, O.R, Otusanya, O.O. \& Akpor, O.B. (2009). Allelopathic effect of Tithonia diversifolia on the germination, growth, and chlorophyll content on maize (Zea mays L.). Scientific Research and Essay, 4(12), 1553-1558.

Phiri, S., Rao, I.M., Barrios, E. \& Singh, B.R. (2003). Plant growth, mycorhiza association, nutrient uptake, and phosphorus dynamics in a volcanic-ash soil in Colombia as a affected by the establishment of 
Tithonia diversifolia. Journal of Sustainable Agriculture, 21(3), 41-59. DOI: https://doi.org/ 10.1300/J064v21n03 05.

Prasetyo, B. H. \& Suriadikarta, D.A. (2016). Karakteristik, potensi dan teknologi pengelolaan tanah ultisol untuk pengembangan pertanian lahan kering di Indonesia. Jurnal Litbang Pertanian, 25(2), 39-47.

Raja, L.S.B., Damanil, B.S.J. \& Ginting, J. (2013). Respon pertumbuhan dan produksi kacang tanah terhadap bahan organik Tithonia diversifolia dan pupuk SP-36. Jurnal Online Agroekoteknologi, 3(1), 725-731.
Sinclair, J.B. 1994. Soybeans. In W.F. Bennett (Ed.). Nutrient Deficiencies and Toxicities in Crop Plant. American Phytopatological Society, Minnesota.

Sutedjo, M.M. 2002. Pupuk dan Cara Pemupukan. Rineka Cipta, Jakarta. 